Article

\title{
Anti-Tumour Promoting Activity and Antioxidant Properties of Girinimbine Isolated from the Stem Bark of Murraya koenigii S.
}

Yih Yih Kok ${ }^{1,2}$, Lim Yang Mooi ${ }^{1,3}$, Kartini Ahmad ${ }^{4,5}$, Mohd Aspollah Sukari ${ }^{4}$, Nashriyah Mat $^{6}$, Mawardi Rahmani ${ }^{4}$ and Abdul Manaf Ali ${ }^{1,6, *}$

1 Department of Cell and Molecular Biology, Universiti Putra Malaysia, 43400 UPM Serdang, Selangor, Malaysia; E-Mails: yihyih_kok@imu.edu.my (Y.Y.K.); ymlim@utar.edu.my (L.Y.M.)

2 Department of Human Biology, International Medical University, 126 Jalan Jalil Perkasa 19, Bukit Jalil, 57000 Kuala Lumpur, Malaysia

3 Department of Preclinical Sciences, Universiti Tunku Abdul Rahman, Lot PT21144, Jalan Sungai Long, 43000 Kajang, Selangor, Malaysia

4 Department of Chemistry, Universiti Putra Malaysia, 43400 UPM Serdang, Selangor, Malaysia; E-Mails: kartini@fsmt.upsi.edu.my (K.A.); aspollah@science.upm.edu.my (M.A.S.); mawardi@science.upm.edu.my (M.R.)

5 Department of Chemistry, Faculty of Science and Mathematics, Universiti Pendidikan Sultan Idris, 35900 Tanjong Malim, Perak, Malaysia

6 Faculty of Agriculture and Biotechnology, Universiti Sultan Zainal Abidin, Gong Badak Campus, 21300 Kuala Terengganu, Terengganu, Malaysia; E-Mail: nashriyah@unisza.edu.my (N.M.)

* Author to whom correspondence should be addressed; E-Mail: manaf@unisza.edu.my; Tel.: + 609-622-0707; Fax: +609-627-5574.

Received: 26 December 2011; in revised form: 5 April 2012 / Accepted: 11 April 2012 / Published: 20 April 2012

Abstract: Girinimbine, a carbazole alkaloid isolated from the stem bark of Murraya koenigii was tested for the in vitro anti-tumour promoting and antioxidant activities. Anti-tumour promoting activity was determined by assaying the capability of this compound to inhibit the expression of early antigen of Epstein-Barr virus (EA-EBV) in Raji cells that was induced by the tumour promoter, phorbol 12-myristate 13-acetate. The concentration of this compound that gave an inhibition rate at fifty percent was $6.0 \mu \mathrm{g} / \mathrm{mL}$ and was not cytotoxic to the cells. Immunoblotting analysis of the expression of EA-EBV showed that girinimbine was able to suppress restricted early antigen (EA-R). However, diffused early antigen (EA-D) was partially suppressed when used at $32.0 \mu \mathrm{g} / \mathrm{mL}$. Girinimbine exhibited a very strong antioxidant activity as compared to $\alpha$-tocopherol and 
was able to inhibit superoxide generation in the 12-O-tetradecanoylphorbol-13-acetate (TPA)-induced differentiated premyelocytic HL-60 cells more than 95\%, when treated with the compound at 5.3 and $26.3 \mu \mathrm{g} / \mathrm{mL}$, respectively. However girinimbine failed to scavenge the stable diphenyl picryl hydrazyl (DPPH)-free radical.

Keywords: Murraya koenigii; girinimbine; anti-tumour promoting activity; antioxidative; superoxide

\section{Introduction}

Murraya koenigii is one of the two species of Murraya found in Peninsular Malaysia [1]. The plant is known locally as curry leaf due to its aromatic smell. The leaves are used as traditional vegetable (ulam), which help promote appetite and digestion, and provide natural flavouring in curries [2]. Various parts of this plant were used to cure several diseases. For example, the leaves are used to treat diarrhoea, dysentery and digestive disorder [3]. The leaves are also used in Indian traditional medicine to prevent and cure diabetes. It was reported that the leaves inhibit $\alpha$-amylase and also increased insulin production in animal models [4]. The roots are used to cure piles, inflammation and itching, while powdered leaves are used to aid healing of fresh cuts [5]. The barks and roots are also used to relieve skin eruptions and bites by poisonous animals [6]. The leaves were reported to have a very strong antioxidative activity $[7,8]$ and the methanolic extract of the leaves contain antinematodal activity against the pine wood nematode, Bursaphelenchus xylophilus [9].

Murraya koenigii is known to be the richest source of carbazole alkaloids [10-13]. Girinimbine (Figure 1), together with mahanimbine and murrayanine, were isolated from the barks of stem of M. koenigii [13]. Total syntheses through novel synthetic methods of all these carbazole alkaloids which are biologically active have been reported by Knolker and Reddy [14] and Knolker [15]. Furthermore, highly efficient routes to the carbazole girinimbine were also established [16,17]. Ko et al. [18] have reported that girinimbine isolated from M. euchrestifolia was shown to have anti-platelet activity through the inhibition of cyclooxygenase activity. The compound was reported to be cytotoxic to various cell lines which caused the cells to die through apoptosis cell death $[19,20]$.

Figure 1. Girinimbine.

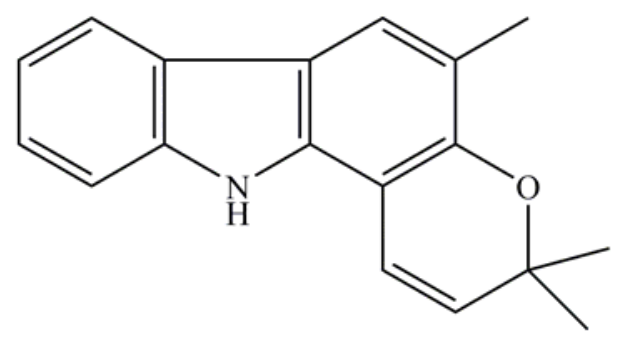

In this paper, we report that girinimbine isolated from the stem bark of $M$. koenigii possesses a very strong anti-tumour promoting activity when assayed for the inhibition of early antigen expression of Epstein-Barr virus in Raji cells but compound was not cytotoxic to the cells. This compound was 
shown to have a strong antioxidant activity as assayed using the ferric thiocyanate method and inhibition of superoxide $\left(\mathrm{O}_{2}{ }^{-}\right)$generation in the TPA-induced promyelocytic HL-60 cells.

\section{Results and Discussion}

The in vitro anti-tumour promoting activity of girinimbine was determined by measuring the percentage inhibition of induced early antigen (EA) of EBV on the surface of Raji cells. Raji cells are B-human lymphoblastoids latently infected with EBV, in which the early antigen of the virus can be induced by phorbol 12-myristate 13-acetate and $n$-butyrate to express on the surface of cells which can be detected by imunofluorescence using human antisera of nasopharyngeal carcinoma [21]. In this study, we have shown that girinimbine strongly inhibited the induction of EA of EBV more than $90 \%$ when tested at 16.0 and $32.0 \mu \mathrm{g} / \mathrm{mL}$. The inhibition rate was moderate when tested at $8.0 \mu \mathrm{g} / \mathrm{mL}$ (inhibition rate 58\%) and low at 4.0, 2.0 and $1.0 \mu \mathrm{g} / \mathrm{mL}$ (inhibition rates of 46,35 and $32 \%$, respectively). The inhibition rate at fifty percent of the compound extrapolated from the dose response curve was $6.0 \mu \mathrm{g} / \mathrm{mL}$ (Figure 2). The compound was not cytotoxic to the Raji cells where the viability of the cells was more than $90 \%$ at all the concentration tested.

Figure 2. Effect of girinimbine on the early antigen (EA) of Epstein-Barr virus activation and the viability of Raji cells.

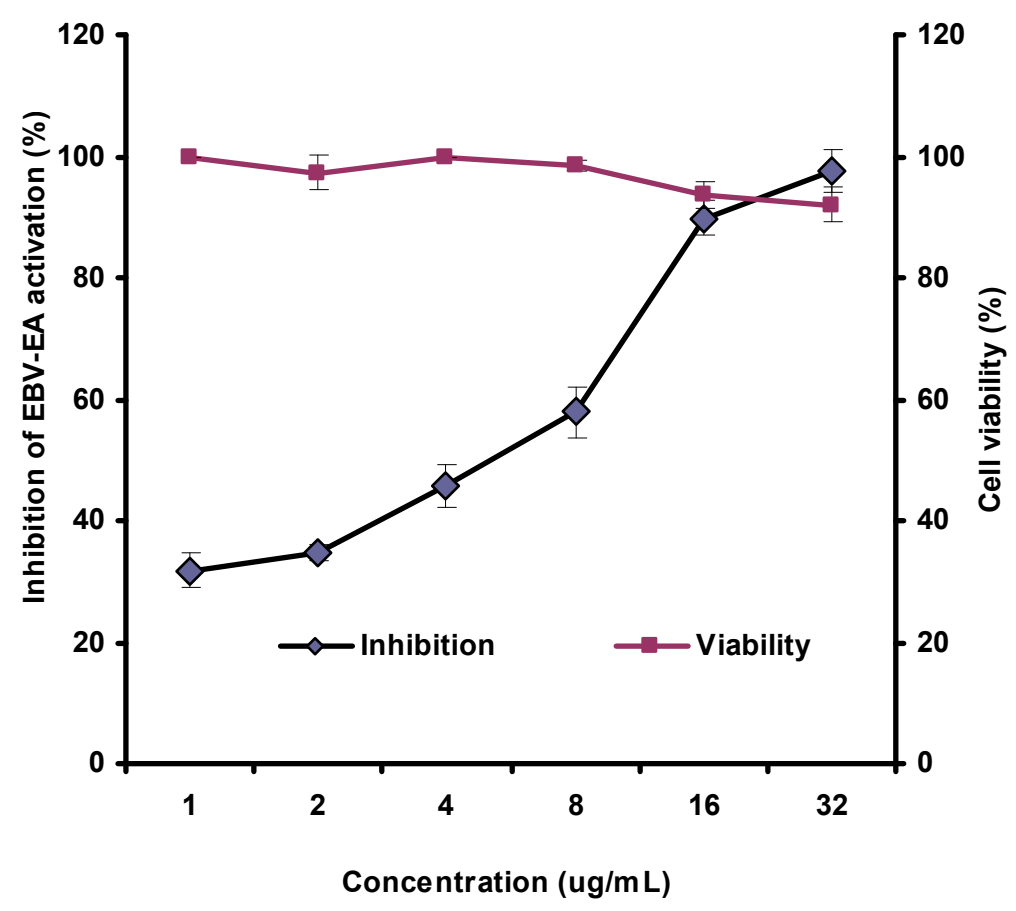

The immunoblotting analysis of EBV-early protein diffused (D) and restricted (R) from Raji cells, induced by PMA and sodium- $n$-butyrate were studied with different concentrations of girinimbine. The EBV-EA classified into diffused type (EA-D), which can be detected both in the nucleus and the cytoplasm as a high intensity $50-52 \mathrm{kDa}$ protein band. The restricted type (EA-R) is only detected in the cytoplasm which can be observed as a less intense $85 \mathrm{kDa}$ protein band [22,23]. Figure 2 shows Raji cells induced with PMA and $n$-butyrate expressed both EA-R and EA-D whereas untreated cells and cells treated only with sodium- $n$-butyrate only expressed EA-R. A similar observation was 
reported by Ali et al. [22] and Kondo et al. [23]. In this study, the EA-R was completely suppressed by girinimbine at all concentrations tested $(1.0,2.0,4.0,8.0,16.0$ and $32.0 \mu \mathrm{g} / \mathrm{mL})$. On the other hand, the EA-D was partially suppressed only at a concentration of $32.0 \mu \mathrm{g} / \mathrm{mL}$ (Figure 3).

Figure 3. Effects of different concentrations of girinimbine on the synthesis of EBV-early protein diffuse (EA-D) (bottom arrow) and restricted (EA-R) (top arrow) from Raji cells treated with phorbol 12-myristate 13-acetate (PMA, $0.05 \mu \mathrm{M}$ ) and sodium- $n$-butyrate (3 $\mathrm{mM}$ ) by immunoblotting analysis. Lane 1 was the pre-stained SDS-PAGE standard, mid-range marker. Lane 2 is the untreated Raji cells $(\mathrm{C} 1)$, Lane 3 is sodium- $n$-butyrate treated Raji cells (C2), Lane 4 is PMA and sodium- $n$-butyrate treated Raji cells (C3), Lanes 5 to 10 are Raji cells treated with girinimbine ( 1 to $32 \mu \mathrm{g} / \mathrm{mL}$ ).

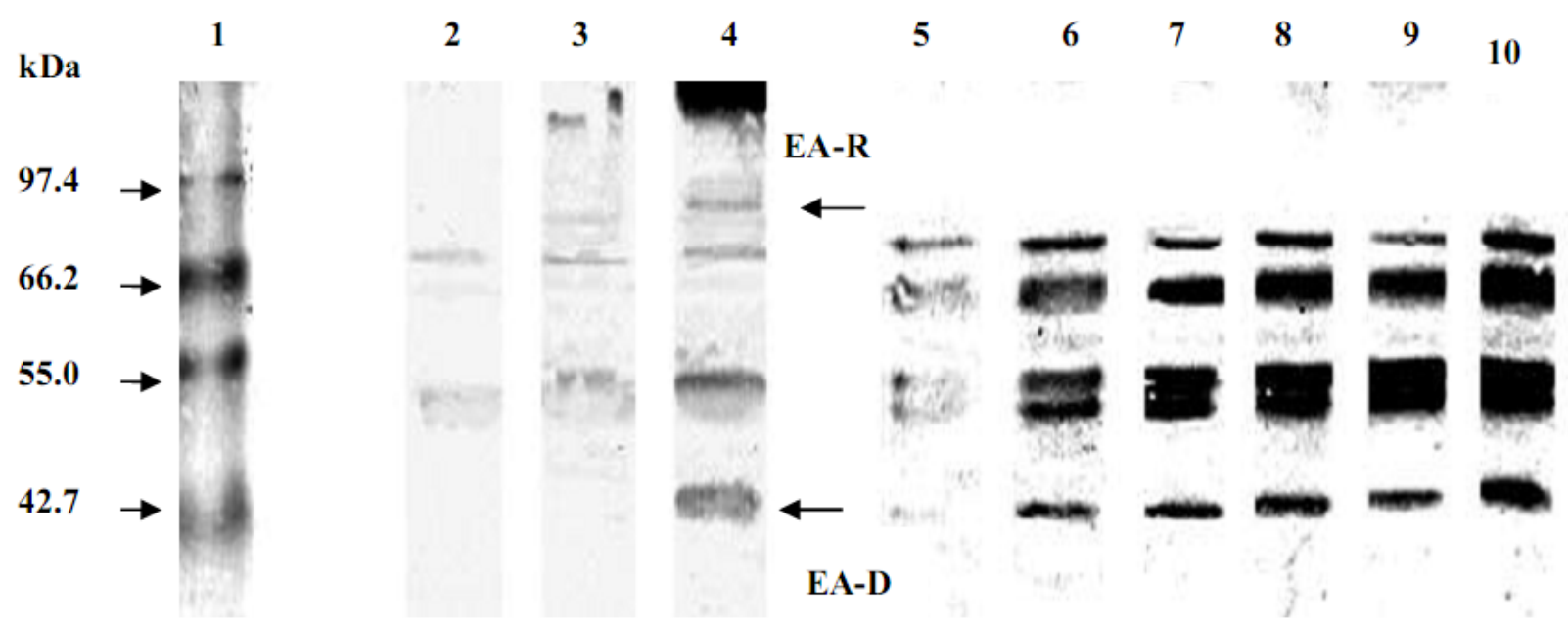

The antioxidative activity of girinimbine was measured by the FTC method at a concentration of $0.02 \%$ in an aqueous ethanolic solution. The FTC method measures the amount of peroxide produced during initial stages of lipid oxidation. During the oxidation process, peroxide was gradually decomposed to lower molecule compounds that gave red colour, which can be measured at $500 \mathrm{~nm}$ wavelength.

Figure 4 shows girinimbine exhibited a very strong antioxidant property which was the same as that vitamin $\mathrm{E}$ ( $\alpha$-tocopherol). However, this compound failed to scavenge the diphenyl picryl hydrazyl (DPPH) free radical whereas $\alpha$-tocopherol did (result not shown). The ability of girinimbine to inhibit the generation of superoxide anion radicals $\left(\mathrm{O}_{2}{ }^{-}\right)$was carried out using the TPA-induced promyelocytic HL-60 cells [24]. Inhibition rate of superoxide anion radicals was at 98.7 and 95.6\% when TPA-induced HL-60 cells were treated with girinimbine at the concentrations of 5.3 and $26.3 \mu \mathrm{g} / \mathrm{mL}$, respectively. However, at concentrations of 0.2 and $1.1 \mu \mathrm{g} / \mathrm{mL}$ the inhibition rate was below 20\% (Figure 5). Free radicals have been reported to cause mutagenicity, cytotoxicity and stimulate changes in gene expression. Hydroxyl radicals that form from superoxide anion or hydrogen peroxide are highly active oxygen species which can react directly with DNA, protein and unsaturated lipids of cell. The damaged protein, DNA and lipid peroxidation can cause membrane damage, altered receptor functionality and eventually lead to cell damage. The mechanism of action of girinimbine to inhibit tumour promotion may involve the suppression of $\mathrm{O}_{2}{ }^{-}$induced by TPA, since free radicals are reported to participate in altering gene expression during tumour promotion [25]. 
Figure 4. Antioxidant activity of girinimbine measured by FTC method.

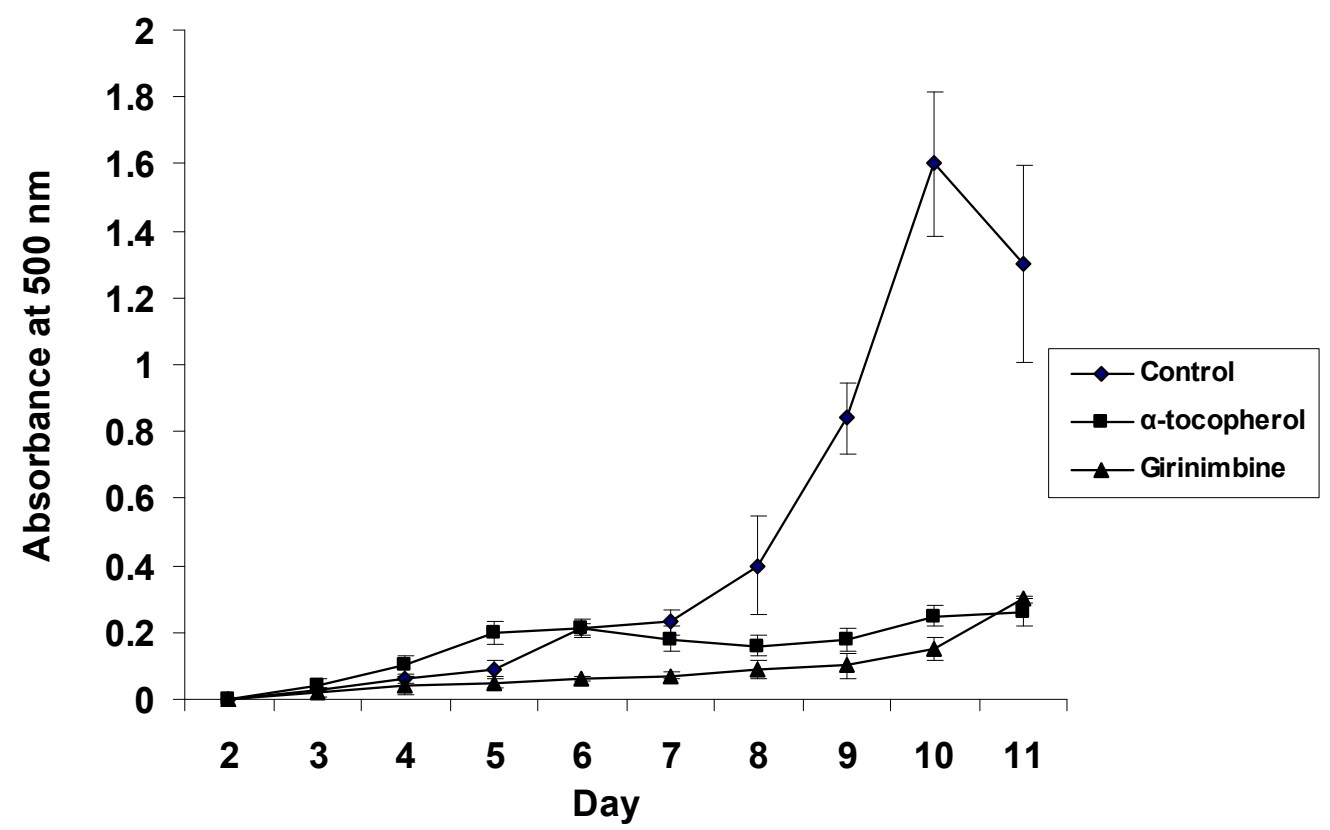

Figure 5. Inhibitory effect of girinimbine on the superoxide generation in differentiated HL60 cells.

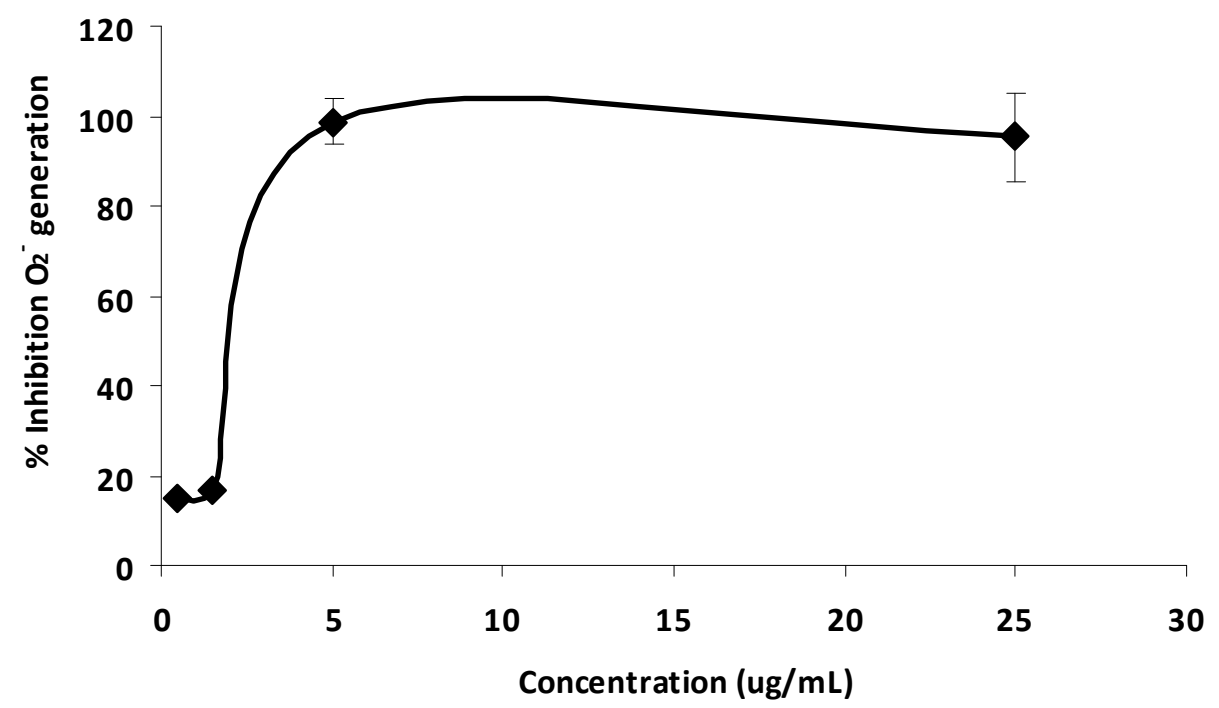

\section{Experimental}

\subsection{Isolation of Girinimbine}

The stem bark of M. koenigii used in this study was collected from Banting, Selangor, Malaysia. Airdried stem bark $(1,100 \mathrm{~g})$ was ground into fine powder and extracted by soaking for three days with petroleum ether. The extract was subjected to column chromatography on silica gel eluted with $\mathrm{CHCl}_{3}$ to afford girinimbine [26]. 


\subsection{Cell Culture}

The Raji (human B-lymphoblastoid) cell line was provided by Prof. K. Koshimizu, Kinki University, and premyelocytic HL-60 cell line was obtained from the RIKEN Cell Bank, Tsukuba, Japan. Cells were cultured in RPMI-1640 (Sigma, St. Louis, MO, USA) medium with 10\% (v/v) foetal calf serum (Sera Lab, Sussex, UK), $100 \mathrm{IU} / \mathrm{mL}$ penicillin (Sigma, St. Louis, MO, USA) and $100 \mu \mathrm{g} / \mathrm{mL}$ streptomycin (Sigma, St. Louis, MO, USA) as a complete growth medium (CGM). Cells were maintained in $25 \mathrm{~cm}^{3}$ flask with $10 \mathrm{~mL}$ of $\mathrm{CGM}$ at $37{ }^{\circ} \mathrm{C}$ with $5 \% \mathrm{CO}_{2}$. Every three days, the cells were sub-cultured by splitting the culture with fresh CGM at a ratio of 2:8. Cell viability was determined using microtetrazolium assay (MTT) as described previously by Mackeen et al. [27].

\subsection{Inhibitory Assay of Epstein Barr Virus Activation}

The assay was carried out as described by Mooi et al. [21]. Briefly, Raji cells at a concentration of $5 \times 10^{5}$ cells $/ \mathrm{mL}$ were incubated in $1 \mathrm{~mL}$ of RPMI 1640 medium (supplemented with $10 \%$ fetal calf serum) containing sodium- $n$-butyrate $(3 \mathrm{mM})$, phorbol 12 -myristate 13 -acetate $(0.05 \mu \mathrm{M})$ and test substance $(5 \mu \mathrm{L})$ at $37{ }^{\circ} \mathrm{C}$ under $5 \% \mathrm{CO}_{2}$ for $48 \mathrm{~h}$. Early antigen (EA) expressed in Raji cells was detected by an indirect immunoflourescence method, with EA-positive sera from NPC (nasopharyngeal carcinoma) patients of the Hospital University of the University of Malaya and FITC-labeled IgG (Sigma). The average EA induction was compared to a control with only PMA and sodium- $n$-butyrate, the induction rate of the control was less than $40 \%$.

\subsection{Immunoblotting Analysis for the Detection of EBV-early Antigen on PVDF Membrane}

Immunoblotting of treated and untreated Raji cells was carried out as described by Ali et al. [22]. The cells were washed twice with PBS at $4{ }^{\circ} \mathrm{C}$. The cells were spun down at $3,000 \mathrm{~g}$ for $5 \mathrm{~min}$ at $4{ }^{\circ} \mathrm{C}$ and resuspended in five volumes of ice-cold suspension buffer. An equal volume of $2 \times$ SDS gel-loading buffer was added, followed by boiling the samples for $10 \mathrm{~min}$. The lysates were centrifuged at $10,000 \times g$ for $10 \mathrm{~min}$. A volume of $15 \mu \mathrm{L}$ each of the samples and $3 \mu \mathrm{L}$ of pre-stained SDS-PAGE standards of mid range molecular weight markers (Bio-Rad, Hercules, CA, USA) were loaded into the pre-determined order wells on a 12\% SDS-polyacrylamide slab gel [28]. The SDS-polyacrylamide gel containing separated proteins were electrophoretically transferred to a PVDF membrane. The membrane was then stained with NPC serum in the ratio of 1:20, followed by the enzyme-coupled secondary antibody (affinity purified Goat anti Human IgG Horseradish Peroxidase Conjugate (KPL, Gaithersburg, MD, USA)) in the 1:200 ratio with a final concentration of $0.5 \mu \mathrm{g} / \mathrm{mL}$. The immunoreactive bands in the PVDF membranes were developed with colour development solution consisting of $2 \%$ of 4-chloro-1-naphthol (4CN) (Bethesda Research Lab., Gaithersburg, MD, USA) as substrate for Horseradish Peroxidase (HP), $50 \mathrm{~mL}$ of Tris $\mathrm{HCl}$ buffer, $\mathrm{pH} 7.4$ and $30 \mu \mathrm{L}$ of $30 \%$ of $\mathrm{H}_{2} \mathrm{O}_{2}$.

\subsection{Antioxidant Assay (Ferric Thiocyanate Method)}

The ferric thiocyanate method of antioxidant assay was carried out according to Mohamed et al. [29]. Exactly $2 \mathrm{mg}$ of compound was dissolved in of absolute ethanol $(4 \mathrm{~mL})$ in a vial with a screw cap 
$(\phi 38 \times 75 \mathrm{~mm})$. Then, of $2.51 \%$ of linolenic acid $(4.1 \mathrm{~mL}$, TCI, Tokyo, Japan) in ethanol was added and this was followed by addition of $0.02 \mathrm{M}(\mathrm{pH}$ 7) phosphate buffer $(8 \mathrm{~mL})$. Lastly, deionised water was added $(3.9 \mathrm{~mL})$ and the cap was screw-locked and incubated in an oven at $40{ }^{\circ} \mathrm{C}$ in the dark. To an aliquot of this $(0.1 \mathrm{~mL}), 75 \%$ ethanol $(\mathrm{v} / \mathrm{v}, 9.7 \mathrm{~mL})$ and $30 \%$ ammonium thiocyanate $(0.1 \mathrm{~mL})$ were added. Precisely $3 \mathrm{~min}$ after addition of $0.02 \mathrm{M}$ ferrous chloride in $3.5 \%$ hydrochloric acid $(0.1 \mathrm{~mL})$ to the tube, the mixture was shaken and the absorbance was measured at $500 \mathrm{~nm}$ wavelength by using a spectrophotometer (Spectronic 20D+, Rochester, NY, USA) for every $24 \mathrm{~h}$ until the control reached its maximum absorbance value.

\subsection{Diphenyl Picryl Hydrazyl (DPPH) Free Radical Scavenger Assay}

Stock solution of the compound at $1 \mathrm{mg} / \mathrm{mL}$ was prepared in methanol. The stock solution was diluted to varying concentrations in a volume of $100 \mu \mathrm{L}$ and was carried out in a 96-well microtiter plate. A volume of $5 \mu \mathrm{L}$ of diphenyl- $\rho$-picrylhydrazine (DPPH) solution ( $10 \mathrm{mg} / \mathrm{mL}$ in methanol) was added into each well. The plate was kept in the dark for $30 \mathrm{~min}$ and the optical density of the wells was measured at a wavelength of $517 \mathrm{~nm}$ by using an ELISA Reader (Biotek, Winooski, VT, USA) [29].

\subsection{TPA-induced Superoxide Generation Test}

The assay was performed by using the differentiated human premyelocytic leukemia (HL-60) cells, as described by Nakamura et al. [24]. The cells were stimulated to differentiate into granulocyte-like cells by pre-incubation with $1.25 \%$ of DMSO in RPMI 1640 medium, supplemented with 10\% FBS at $37{ }^{\circ} \mathrm{C}$ in $5 \% \mathrm{CO}_{2}$ incubator for 4 to 6 days. The cells were washed with Hanks buffer (HBSS) and suspended at a density of $1 \times 10^{6}$ cells $/ \mathrm{mL}$. Exactly $5 \mu \mathrm{L}$ of test substance dissolved in DMSO was added into the $1 \mathrm{~mL}$ cell suspension and incubated at $37{ }^{\circ} \mathrm{C}$ for $15 \mathrm{~min}$. The cells were washed twice with HBSS to remove the extracellular test substance. Ninety sec after stimulation with 12- $O$-tetradecanoylphorbol-13-acetate (TPA) $(20 \mu \mathrm{M}), 50 \mu \mathrm{L}$ of cytochrome $\mathrm{C}(20 \mu \mathrm{g} / \mathrm{mL})$ was added to the cell suspension and was incubated for another $15 \mathrm{~min}$ at $37{ }^{\circ} \mathrm{C}$. The reaction mixture was stopped by placing it on ice and spun down at 2,000 $\times \mathrm{g}$ for $1 \mathrm{~min}$. The visible absorption of the supernatant at $550 \mathrm{~nm}$ wavelength was determined. The level of $\mathrm{O}_{2}{ }^{-}$production was calculated by the following equation (1). The mean value of triplicate was obtained:

$$
\left[\mathrm{O}_{2}^{-}(\mathrm{nmol} / \mathrm{mL})=47.7 \times \mathrm{A} 550 \mathrm{~nm}\right]
$$

All the data obtained the experiments were triplicate and for the cell viability, inhibitory of Epstein-Barr virus the data were expressed as percentage of control.

\section{Conclusions}

Girinimbine, a carbazole alkaloid isolated from the stem bark of Murraya koenigii inhibited the expression of early antigen of Epstein Barr virus (EA-EBV) in Raji cells that was induced by tumour promoter, phorbol 12-myristate 13-acetate. The compound was able to suppress restricted early antigen (EA-R) however, diffused early antigen (EA-D) was partially suppressed when used at $32.0 \mu \mathrm{g} / \mathrm{mL}$. A very strong antioxidant activity was exhibited by girinimbine which was comparable to that of 
$\alpha$-tocopherol. The compound was also inhibited the superoxide generation in the TPA-induced differentiated premyelocytic HL-60 cells.

\section{Acknowledgements}

This project was partly supported by the Japanese International Cooperation Agency (JICA) and NEDO. The authors would like to acknowledge the financial support for this project by the Ministry of Science Technology and Innovation, Malaysia.

\section{References}

1. Sasteri, B.N. The Wealth of India. In A Dictionary of Indian Raw Material and Industrial Products; Council of Scientific and Industrial Research (CSIR): New Delhi, India, 1952; Volume 6, pp. 446-447.

2. Mackeen, M.M.; Ali, A.M.; El-Sharkawy, S.H.; Manap, M.Y.; Salleh, K.M.; Lajis, N.H.; Kawazu, K. Antimicrobial and cytotoxic properties of some Malaysian traditional vegetables (ulam). Pharm. Biol. 1997, 35, 174-178.

3. Drury, H.C. The Useful Plants of India, 2nd ed; Allen: London, UK, 1978; p. 78.

4. Lawal, H.A.; Atiku, M.K.; Khelpa, D.G.; Wannang, N.H. Hypoglycaemic and hypolipidaemic effect of aqueous leaf extract of Murraya koenigii in normal and alloxan-diabetic rats. Niger. J. Physiol. Sci. 2008, 23, 37-40.

5. Vinuthan, M.K.; Girish Kumar, V.; Ravindra, J.P.; Jayaprakash; Nayarana, K. Effects of extracts of Murraya koenigii leaves on the levels of blood glucose and plasma insulin in alloxan-induced diabetic rats. Indian J. Physiol. Pharmacol. 2004, 48, 348-352.

6. Dastur, J.F. Medicinal Plants of India and Pakistan, 3rd ed.; Tarapovela Sons: Bombay, India, 1970; p. 115.

7. Tachibana, Y.; Kikuzaki, H.; Lajis, N.H.; Nakatani, N. Antioxidative activity of carbazoles from Murraya koenigii leaves. J. Agric. Food Chem. 2001, 49, 5589-5594.

8. Tachibana, Y.; Kikuzaki, H.; Lajis, N.H.; Nakatani, N. Comparison of oxidative properties of carbazoles alkaloids from Murraya koenigii leaves. J. Agric. Food Chem. 2003, 51, 6161-6167.

9. Mackeen, M.M.; Ali, A.M.; Abdullah, M.A.; Nasir, R.M.; Mat, N.B.; Razak, A.R.; Kawazu, K. Antinematodal activity of some Malaysian plant extracts against the pine wood nematode, Bursaphelenchus xylophilus. Pestic. Sci. 1997, 51, 165-170.

10. Chakraborty, M.; Nath, A.C.; Khasnobis, S.; Chakrabarty, M.; Konda, Y.; Harigaya, Y.; Komiyama, K. Carbazole alkaloids from Murraya koenigii. Phytochemistry 1997, 46, 751-755.

11. Reisch, J.A.C.; Adebajo, V.; Kumar; Aladesami, A.J. Two carbazole alkaloids from Murraya koenigii. Phytochemistry 1994, 36, 1073-1076.

12. Ramsewak, R.S.; Nair, M.G.; Strasburg, G.M.; DeWitt, D.L.; Nitiss, J.L. Biologically active carbazole alkaloids from Murraya koenigii. J. Agric. Food Chem. 1999, 47, 444-447.

13. Sukari, M.A.; Ahmad, K.; Ali, A.M.; Amin, N.M.; Aimi, N.; Kitajima, M.; Rahmani, M. Chemical constituents of stem bark of Murraya koenigii S. J. Trop. Med. Plant. 2000, 1, 20-24.

14. Knolker, H.-J.; Reddy, K.R. Isolation and synthesis of biologically active carbazole alkaloids. Chem. Rev. 2002, 102, 4303-4427. 
15. Knolker, H.-J. Transition metal complexes in organic synthesis, part 70\#. Synthesis of biologically active carbazole alkoloids using organanometallic chemistry. Curr. Org. Synth. 2004, 1, 309-3321.

16. Gruner, K.K.; Knolker, H.-J. Palladium-catalyzed total synthesis of euchrestifoline using a one-pot Wacker oxidation and double aromatic $\mathrm{C}-\mathrm{H}$ bond activation. Org. Biomol. Chem. 2008, 6, 3902-3904.

17. Gruner, K.K.; Hopfmann, T.; Matsumoto, K.; Jager, A.; Katsuki, T.; Knolker, H.-J. Efficient iron-mediated approach to pyrano[3,2-a]carbazole alkaloids-First total syntheses of $O$-methylmurrayamine A and 7-methoxymurrayacine, first asymmetric synthesis and assignment of the absolute configuration of (-)-trans-dihydroxygirinimbine. Org. Biomol. Chem. 2011, 9, 2057-2061.

18. Ko, F.N.; Lee, Y.S.; Wu, T.S.; Teng, C.M. Inhibition of cyclooxygenase activity and increase in platelet cyclic AMP by girinimbine isolated from Murraya euchrestifolia. Biochem. Pharmacol. 1994, 48, 353-360.

19. Cui, C.B.; Yan, S.Y.; Cai, B.; Yao, X.S. Carbazole alkaloids as new cell cycle inhibitor and apoptosis inducers from Clausena dunniana Levl. J. Asian Nat. Prod. Res. 2002, 4, 233-241.

20. Syam. S.; Abdul, A.B.; Sukari, M.A.; Mohan, S.; Abdelwahab, S.I.; Wah, T.S. The growth suppressing effects of Girinimbine on HepG2 involve induction of apoptosis and cell cycle arrest. Molecules 2011, 16, 7155-7170.

21. Mooi, L.Y.; Ali, A.M.; Norhanom, A.B.; Salleh, K.M.; Murakami, A.; Koshimizu, K. Anti-tumor promoting activity of some Malaysian traditional vegetables ("ulam"). J. Nat. Prod. Sci. 1999, 5, 33-38.

22. Ali, A.M.; Mooi, L.Y.; Yih, K.Y.; Norhanom, A.B.; Lajis, N.H.; Prasad, U. Anti-tumor promoting activity of plant extracts by immunoblotting analysis of Raji cells carrying Eptein-Barr virus genome. J. Nat. Prod. Sci. 2000, 6, 147-150.

23. Kondo, A.; Morimoto, T.; Okazaki, K. Detection of anti-tumour promoting activity in Raji cells carrying Epstein-Barr virus genome by Immunoblotting analysis. Biosci. Biotechnol. Biochem. 1998, 62, 377-379.

24. Nakamura, Y.; Ohto, Y.; Murakami, A.; Ohigashi, H. Superoxide scavenging activity of rosmarinic acid from Perilla frutescens Britton var. acura F. viridis. J. Agric. Food Chem. 1998, 46, 4545-4550.

25. Guyton, K.Z.; Kensler, T.W. Oxidative mechanisms in carcinogenesis. Br. Med. Bull. 1993, 49, 523-544.

26. Abubakar, N.H.; Sukari, M.A.; Rahmani, M.; Sharif, M.A.; Khalid, K.; Yusof, U.K. Chemical Constituents from stem barks and roots of Murraya koenigii (Rutaceae). Malays. J. Anal. Sci. 2007, 11, 173-176.

27. Mackeen, M.M.; Ali, A.M.; Lajis, N.H.; Kawazu, K.; Hassan, Z.; Amran, M.; Habsah, M.; Mooi, L.Y.; Mohamad S.M. Antimicrobial, antioxidant, anti-tumor promoting and cytotoxic activities of different plant part extracts of Garcinia atroviridis Griff ex T. Anders. $J$. Ethnopharmacol. 2000, 72, 395-402.

28. Laemmmi, U.K. Cleave of structural proteins during the assembly of the head of bacteriophage T4. Nature 1970, 227, 680-685. 
29. Mohamed, H.; Abas, F.; Permana, D.; Lajis, N.H.; Ali, A.M.; Shukari, M.A.; Hin, T.Y.Y.; Kikuzaki, H.; Nakatani, H. DPPH free radical scavenger components from the fruits of Alpinia rafflesiana Wall. ex. Bak. (Zingiberaceae). Z. Naturforsch. C 2004, 59c, 811-815.

Sample Availability: Girinimbine is available from kartini@fsmt.upsi.edu.my.

(C) 2012 by the authors; licensee MDPI, Basel, Switzerland. This article is an open access article distributed under the terms and conditions of the Creative Commons Attribution license (http://creativecommons.org/licenses/by/3.0/). 